Acta vet. scand. $1981,22,369-381$.

From the Department of Reproductive Physiology and Pathology, Veterinary College of Norway, Oslo.

\title{
PLASMA THYROXINE IN THE SOW DURING PREGNANCY AND LACTATION AND DURING RESUMPTION OF OVARIAN ACTIVITY AFTER WEANING*
}

By

Edvard Benjaminsen

\begin{abstract}
BENJAMINSEN, EDVARD: Plasma thyroxine in the sow during pregnancy and lactation and during resumption of ovarian activity after weaning. Acta vet. scand. 1981, 22, 369-381. - Total thyroxine in plasma was studied during pregnancy, lactation and during the post weaning period. The ovarian activity was monitored by progesterone determinations, and oestrous symptoms were recorded. In the two sows studied during pregnancy there was a distinct decrease in total thyroxine values in the last month of pregnancy, reaching a minimum about the time of farrowing. Total thyroxine values stayed low during lactation, but from about the time of weaning and during the following two weeks the concentrations increased rapidly. There was no difference in the thyroxine pattern in sows resuming ovarian activity within normal time (10 days) after weaning ( 72 sows) compared with sows with delayed resumption of ovarian activity (19 sows). The thyroxine level after weaning did not differ between sows with "silent heat" and sows with overt oestrus. Primiparous and pluriparous sows had also similar thyroxine values after weaning. Sows weaned in January-June had a little higher thyroxine concentrations after weaning than sows weaned in July-December. There was a significant negative correlation between number of suckling piglets and thyroxine concentrations before weaning. Free thyroxine index was calculated in some selected samples. The results suggested that the changes observed in total thyroxine reflect changes in the free thyroxine concentrations.
\end{abstract}

thyroxine; sow; pregnancy; lactation; post weaning; reproduction.

Normal thyroid function is considered to be necessary for optimal reproduction. In women hypothyroidism is reported to be related to failure of ovulation and to increased abortion rate

* Financial support was given by the Norwegian Agricultural Research Council. 
(Potter 1980). In the cow, Lennon \& Mixner (1959) found negative correlations between PBI values and interval from first breeding to conception and services per conception. "Silent heat" has also been associated with thyroidectomy or hypothyroidism in the cow (Wilson 1975).

There is little information about the relationship between thyroid function and reproduction in the sow, and information about thyroid activity during the reproductive cycle is also limited (Mølmen 1972, Atinmo et al. 1978, Brenner et al. 1980).

In the present work the thyroid activity was studied in pregnant and in lactating sows and in sows after weaning. It was of special interest to study the relationship between the thyroid function and the ability to resume oestrous activity after weaning.

\section{MATERIALS AND METHODS}

Total plasma thyroxine levels $\left(\mathrm{TT}_{4}\right)$ during pregnancy and lactation were studied in four sows. Two sows were blood sampled, usually once a week, during the last two months of pregnancy and during the first three weeks after farrowing. In these sows farrowing was induced by $10 \mathrm{mg}$ prostaglandin $\mathrm{F}_{2 \alpha}$ (Dinolytic ${ }^{\circledR}$ "Upjohn") on day 113. The other two sows were blood sampled twice a week, from a few days after farrowing until approximately two weeks after weaning.

$\mathrm{TT}_{4}$ levels in plasma during the post weaning period were studied in 92 sows. In a few sows (11) the first sample was taken in the second week before weaning, but in the majority of sows the first sample was taken in the last week before weaning and then weekly, usually until assumed pregnancy.

All sows used were of the Norwegian landrace breed. Feeding and management were of accepted animal husbandry standards. In addition to the naturally occurring iodine in the feed components, $1.4 \mathrm{mg}$ iodine per $\mathrm{kg}$ feedstuff was added. The sows were weaned about six weeks after parturition.

For blood sampling the animals were restrained by a snout rope, and V. jugularis was punctured using heparinized Vacutainers ${ }^{\circledR}$ (Becton, Dickinson, New Jersey, USA) (Benjaminsen \& Karlberg 1979). The samples were centrifuged and the plasma stored at $-20^{\circ} \mathrm{C}$ until analyzed.

Plasma thyroxine was determined by a RIA as described by 
Larsen et al. (1973), with the modifications introduced by Andresen et al. (1980). The values are given in $\mathrm{nmol} / \mathrm{l}(\mathrm{nmol} / \mathrm{l}=$ $\mu \mathrm{g} / 100 \mathrm{ml} \times 12.9)$. The properties of the antiserum have been described (Kruse 1976). The intra-assay coefficient of variation for three samples containing 23, 36 and $62 \mathrm{nmol} / \mathrm{l}$, analyzed with 10 parallels were $7.4 \%, 6.7 \%$ and $5.9 \%$, respectively. The inter-assay variation for three samples containing 24, 45 and 71 nmol/l, analyzed in duplicates on $\mathbf{1 0}$ different days were found to be $11.5 \%, 11.2 \%$ and $8.8 \%$, respectively.

In the two sows sampled through the whole lactation period, and in 22 samples containing high or low $\mathrm{TT}_{4}$, the thyroid hormone uptake test $\left(\mathrm{T}_{3} \mathrm{U}\right)$ was performed. For this analysis the $\mathrm{T}_{3}$ Uptake Diagnostic Kit (Nuclear Medical Laboratories) was used, and free thyroxine index (FTI) was calculated as the product of the $\mathrm{T}_{3} \mathrm{U}$ and the $\mathrm{TT}_{4}$ values.

In order to monitor the ovarian function plasma progesterone was measured in all sows by RIA as previously described (Benjaminsen \& Karlberg 1981). Post weaning oestrus was recorded by the stockman. The progesterone profiles were compared with the time for observed oestrus and in cases with "silent heat" the approximate time for ovulation was determined according to the progesterone profiles.

\section{RESULTS}

Fig. 1 shows $\mathrm{TT}_{4}$ in plasma in the last two months of pregnancy and during early lactation in two sows. The concentrations decreased distinctly from about one month before farrowing and reached a minimum about the time of delivery. The values stayed low during the lactation period (Fig. 2). From about the time of weaning and during the following $\mathbf{1 0}$ days the thyroxine values increased to levels usually found in early pregnancy or in nonpregnant/nonlactating sows.

$\mathrm{TT}_{4}$ in the post weaning period of 92 sows is shown in Fig. 3. The rise of $\mathrm{TT}_{4}$ after weaning was marked and reached a maximum usually in the second week after weaning. Mean $\mathrm{TT}_{4}( \pm \mathrm{s})$ in the last week before weaning was $23.5 \pm 7.3 \mathrm{nmol} / 1$ while the concentration in the second week after weaning was $50.0 \pm 12.2$ $\mathrm{nmol} / \mathrm{l}$.

FTI was closely correlated to $\mathrm{TT}_{4}$ (Fig. 2). Regression analysis of the FTI and TT $_{4}$ values gave the equation $\mathrm{y}=1.2 \mathrm{x}-$ $0.2(\mathrm{r}=0.99, \mathrm{n}=54)$. 


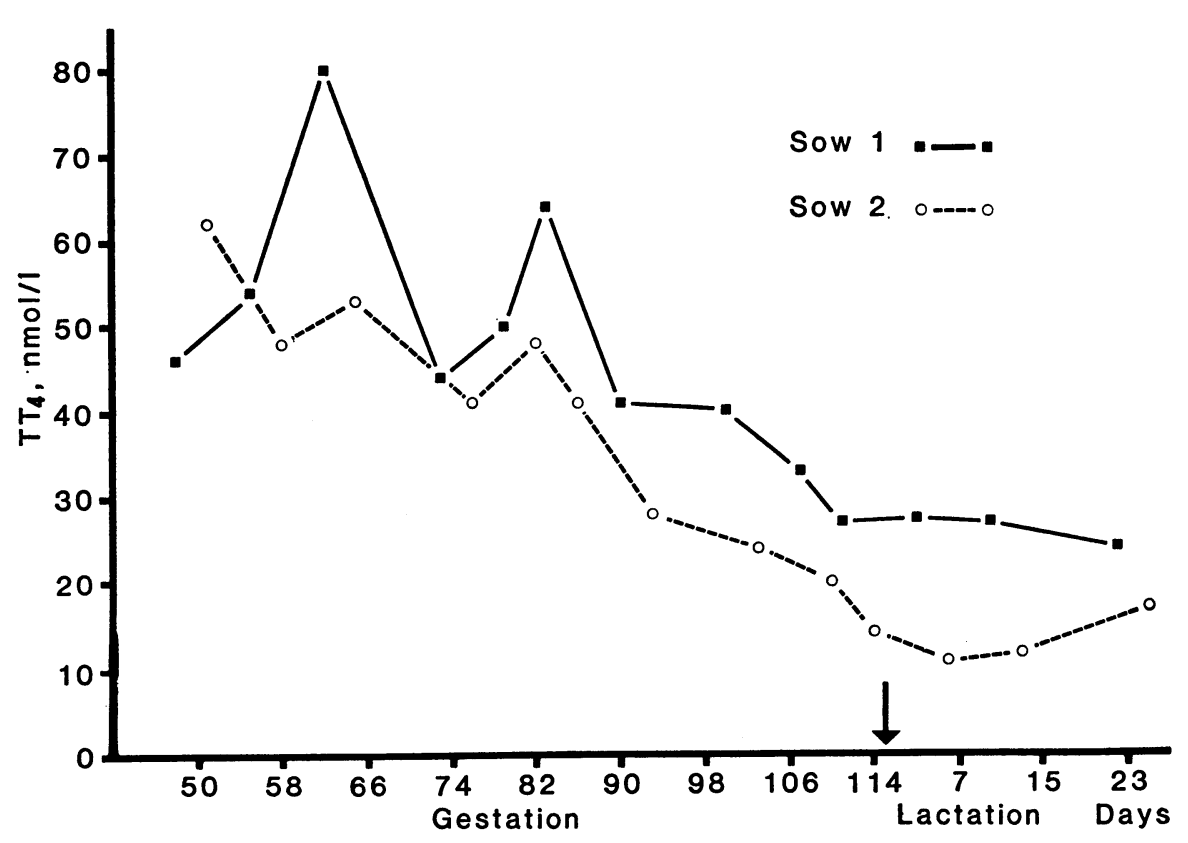

Fig u r e 1. Total plasma thyroxine in 2 sows during second half of gestation and during the first 3 weeks of lactation. Arrow indicates parturition.

Of the 92 sows that were observed through the post weaning period, 19 sows had delayed resumption of ovarian activity as indicated by progesterone levels in plasma. The mean weaningto-ovulation period in these sows was 30-35 days (range: 12 to 55 days), while 72 sows resumed ovarian activity within 10 days post weaning (one sow ovulated before weaning). The $\mathrm{TT}_{4}$ profile in the normal and in the delayed group is illustrated in Fig. 4. There was no difference between $\mathrm{TT}_{4}$ levels in the two groups.

In a few cases the post weaning $\mathrm{TT}_{4}$ increase did not occur or was delayed. This was seen both in sows with early as well as in sows with delayed resumption of ovarian activity after weaning. There were also a few cases with high pre weaning $\mathrm{TT}_{4}$ levels.

Of the 72 sows that resumed ovarian activity at normal time after weaning, 43 showed overt oestrus in connection with the first ovulation, while in 26 sows oestrus was not detected (three sows excluded because of uncertain oestrus detection). The mean $\mathrm{TT}_{4}$ values in these two groups are shown in Fig. 5. The TT 4 profiles were not significantly different. 

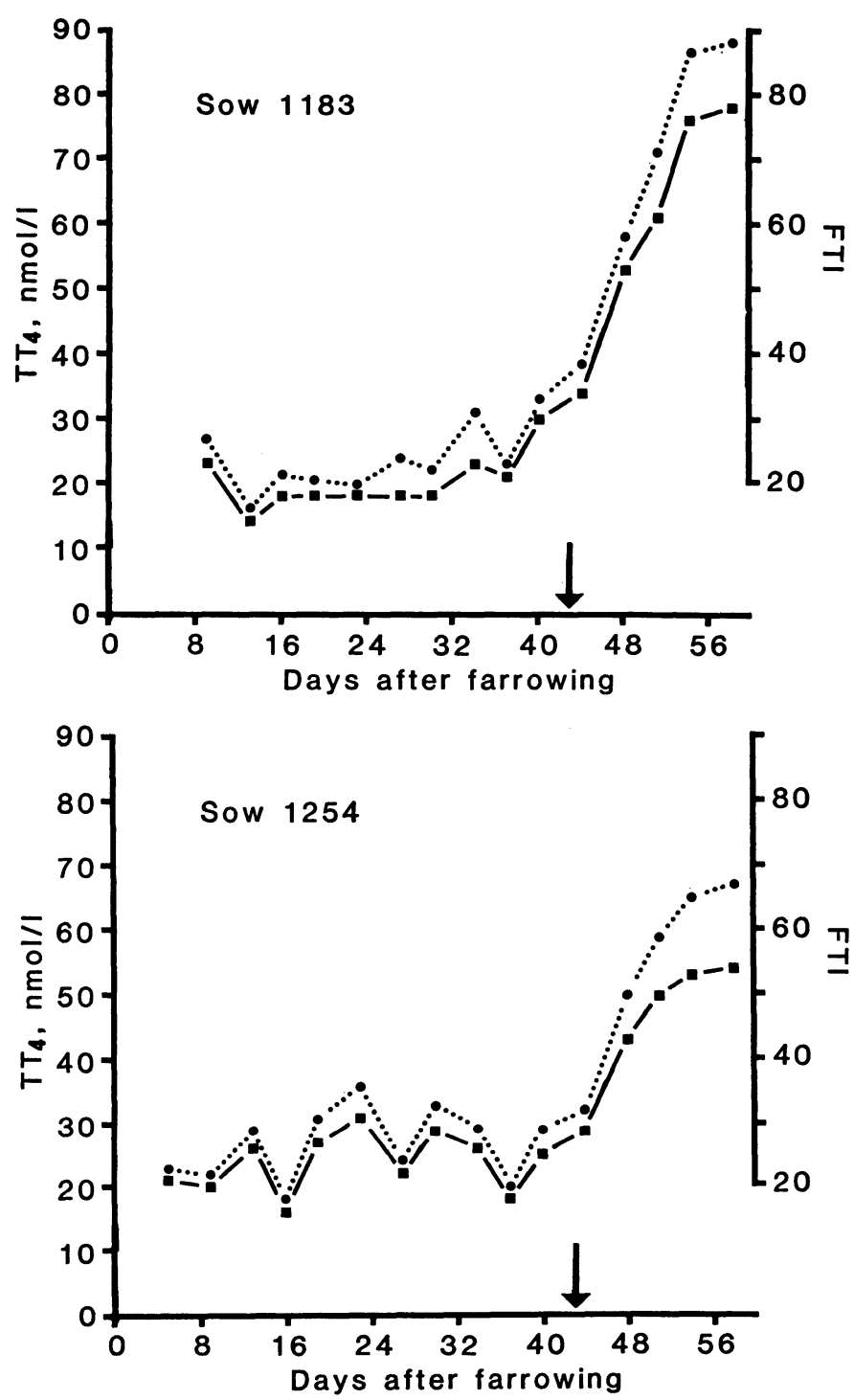

Fig u re 2. Total plasma thyroxine ( $\left.\mathrm{TT}_{4}, \square-\square\right)$ and free thyroxine index (FTI, --- - ) in 2 sows during lactation and after weaning. Arrow indicates weaning. 


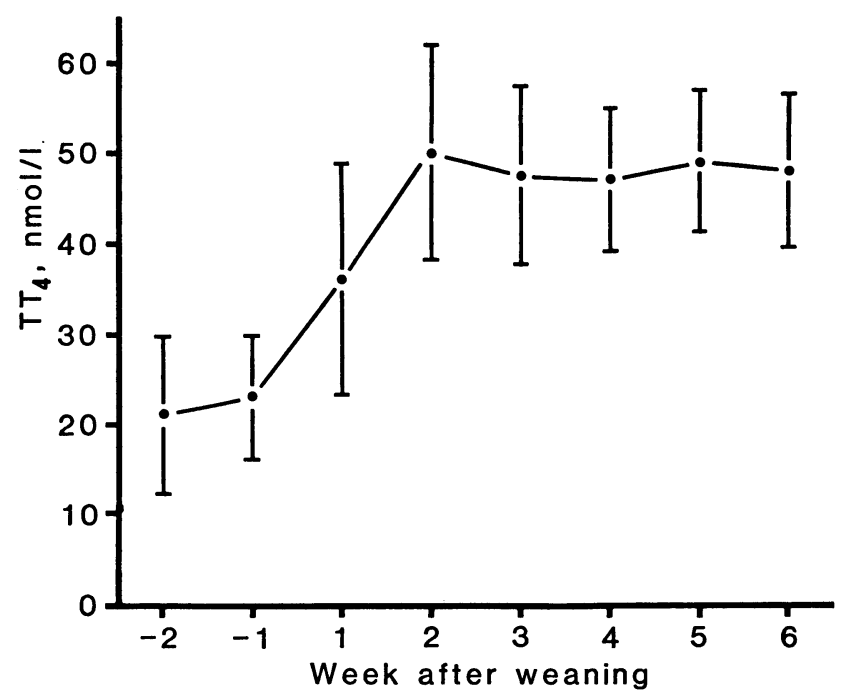

Figure 3. Total plasma thyroxine (mean $\pm s$ ) before and after weaning in 92 sows. (Only 11 observations in week - 2).

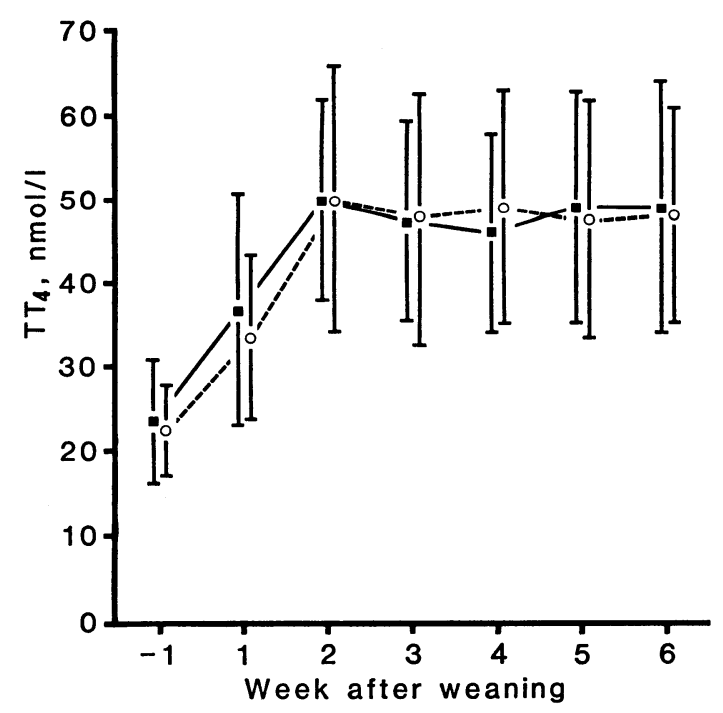

Fig u r e 4. Total plasma thyroxine (mean $\pm s$ ) in sows with normal weaning-to-ovulation period $(\square-\square, n=72)$ and in sows with delayed resumption of ovarian activity after weaning $(O---O, n=19)$. 


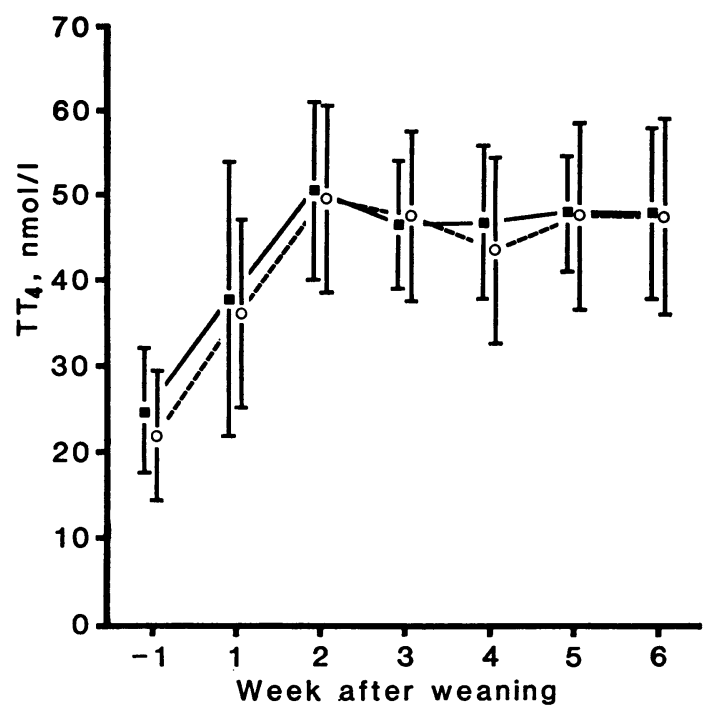

Figur e 5. Total plasma thyroxine (mean $\pm s$ ) in sows with overt oestrus ( $\square, \mathrm{n}=43$ ) and in sows with "silent heat" $\left(0_{---} \mathrm{O}\right.$, $\mathrm{n}=26$ ).

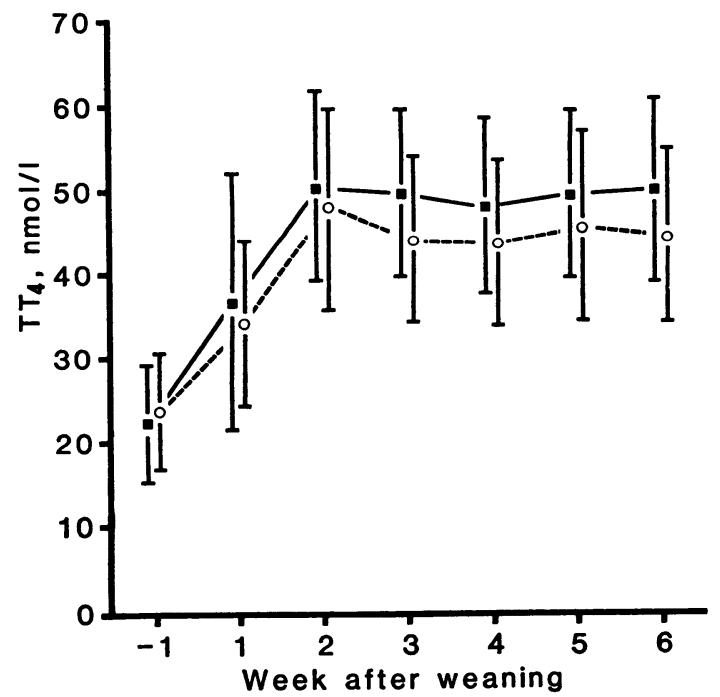

Figure 6. Total plasma thyroxine (mean $\pm s$ ) in sows weaned in January-June $(\square-\square, n=52)$ and in sows weaned in JulyDecember $(O--O, n=40)$. The values were signifjcantly different in week 3 and week $6(P<0.05$, t-test). 
Mean $\mathrm{TT}_{4}$ values in the post weaning period in sows weaned in January-June and in sows weaned in July-December are shown in Fig. 6. Sows weaned in the first half of the year had a little higher $\mathrm{TT}_{4}$ concentrations than sows weaned in the second half of the year.

The values of $\mathrm{TT}_{4}$ after weaning in primiparous sows were not different from those found in pluriparous sows.

There was a significant negative correlation between number of suckling piglets and $\mathrm{TT}_{4}$ concentrations before weaning $(\mathrm{P}<$ $0.01, \mathrm{r}=-0.6$ ).

\section{DISCUSSION}

The $\mathrm{TT}_{4}$ values found during pregnancy and later than two weeks after weaning, are in good agreement with values previously reported in swine (Sutherland \& Irvine 1973, Bakke \& Tveit 1977, Atinmo et al. 1978).

The $\mathrm{TT}_{4}$ values are highly influenced by the concentration of thyroxine binding globulin (TBG). To measure free $T_{4}$ is therefore a better method in evaluating the thyroid status. The FTI is an indirect estimate of free $T_{4}$, and in the human clinic it has proved to be satisfactory (Visscher \& Burger 1980). In the present study a change in $\mathrm{TT}_{4}$ was accompanied by a similar change in FTI. This indicates that the changes in $\mathrm{TT}_{4}$ found reflect changes in the free $T_{4}$ concentrations. However, the usefulness of this test in swine has not been thoroughly investigated (Kallfelz \& Erali 1973).

The observed decrease in $\mathrm{TT}_{4}$ in late pregnancy is consistent with previous reports. Nachreiner \& Ginther $(1972 \mathrm{a}, \mathrm{b})$ found considerably lower values three months after conception and around parturition than earlier in the gestation period. Atinmo et al. reported a decrease in serum thyroxine levels after 10 weeks of gestation. Brenner et al. (1980) also found low $\mathrm{TT}_{4}$ values (about $13 \mathrm{nmol} / \mathrm{l}$ ) in the last three days before farrowing, but higher values (about $38 \mathrm{nmol} / \mathrm{l}$ ) shortly afterwards. Mфlmen (1972), however, did not find any alterations in PBI values during pregnancy. In dairy cows the $\mathrm{TT}_{4}$ concentrations are reported to be lowest in the late stage of gestation (Shoda \& Ishii 1976).

Oestrogens are known to induce a rise in TBG production. In pregnant women the $\mathrm{TT}_{4}$ levels therefore are increased (Gershengorn et al. 1980). Also in the sow the plasma concentrations 
of oestrogens are increased during pregnancy (Robertson \& King 1974). The decreasing $\mathrm{TT}_{4}$ values observed during pregnancy could indicate that oestrogens do not lead to increased TBG production in sows.

One explanation for the low thyroxine values observed in the last part of pregnancy and during lactation could be iodine deficiency. Increased iodine loss during pregnancy could be due to increased renal excretion (Crooks et al. 1967) and placental transfer. In the lactation period iodine is probably lost with the milk. The iodine concentration in sow milk appears to be unknown, but in many other species milk is relatively rich in iodine (Miller et al. 1975). The correlation between $\mathrm{TT}_{4}$ before weaning and number of suckling piglets supports this view. However, the rich iodine supply, probably more than 10 times the requirement (Cunha 1977), rather suggests that the observed changes in $\mathrm{TT}_{4}$ concentrations are caused by physiological mechanisms acting during pregnancy and lactation.

The increase in $\mathrm{TT}_{4}$ after weaning indicates that lactation in some way influences thyroid function. In the sow there is little ovarian activity during lactation. The $\mathrm{LH}$ concentrations in plasma are low with absence of the pulsatile LH secretion pattern (Parvizi et al. 1976). This could be caused by the high prolactin levels during lactation, but it could also be a direct effect of the suckling stimulus (Isherwood \& Cross 1980). It is thus not unlikely that lactation also has an effect on TRH and TSH, and that the intensity of the suckling stimulus (number of suckling piglets) could modulate this mechanism. The decreasing $\mathbf{T T}_{4}$ values observed in the last stage of pregnancy could also be caused by a depressed hypothalamic/hypophyseal activity. A decrease in plasma LH concentrations have been found in the last days of pregnancy (Parvizi et al.). Recently it has been shown that dopamine, which controls the prolactin release and to some extent effects LH secretion (Porter et al. 1980), also is implicated in the control of TSH secretion (Scanlon et al. 1980).

It has been shown in pigs that when feed intake is increased the metabolic rate and the utilization of $T_{4}$ is also increased (Ingram \& Dauncey 1980). In the sows studied, feed consumption increased in the last three weeks of pregnancy, and during lactation the feed consumption was more than doubled compared with the consumption in the post weaning period and in early pregnancy. An effect of high feed intake on the thyroxine utili- 
zation could contribute to the low $\mathrm{TT}_{4}$ values observed in late pregnancy and during lactation in the present study.

Fig. 4 shows that $\mathrm{TT}_{4}$ increased in the same way in sows with delayed resumption of ovarian activity after weaning as in sows with normal ovarian activity. In general there seems to be a connection between thyroid activity and ovarian function. In rabbits, thyroidectomy restricts the ability of the ovaries to ovulate after mating (Thorsøe 1962). A relationship between hypothyroidism and failure of ovulation has also been demonstrated in women (Potter 1980). The present study suggests that low plasma thyroxine is not related to the prolonged ovarian inactivity often seen in the post weaning sow.

There was no difference in the thyroxine pattern between sows with "silent heat" and sows with overt oestrus (Fig. 5). Loss of libido in bulls, rams and boars and suboestrus in cows are reported to be associated with thyroidectomy or hypothyroidism (Wilson 1975). However, Andresen et al. (1980) could not demonstrate any correlation between strength of heat and plasma level of thyroxine in dairy cows.

The difference in thyroxine levels between sows weaned during the autumn season and those weaned during the spring season was small. A seasonal effect on return to oestrous cycle has been demonstrated in the sow (Benjaminsen \& Karlberg 1981), but it is not likely that the small difference in $\mathrm{TT}_{4}$ values observed between seasons has any direct connection with reproduction. The female wild pig in Europe is anoestrous in the late summer and autumn months (Mauget 1978), and the diminished thyroxine levels found in the sows weaned in the period JulyDecember probably reflect a reduced hypothalamic/hypophyseal activity during the months of decreasing daylight length.

\section{ACKNOWLEDGEMENTS}

The antiserum was produced and provided by Dr. V. Kruse, National Institute of Animal Science, Copenhagen. The animals were made available by the Department of Animal Genetics and Breeding, Agricultural University of Norway.

\section{REFERENGES}

Andresen, Ø., J. Amrud, L. E. Grøholt, G. Helland, K.-A. Schie \& G. A. Syllias: Total thyroxine and free thyroxine index of dairy cows in relation to strength of heat. Acta vet. scand. 1980, 21, 108112. 
Atinmo, T., C. Baldijao, W. G. Pond \& R. H. Barnes: The effect of dietary protein restriction on serum thyroxine levels of pregnant or growing swine. J. Nutr. 1978, 108, 1546-1553.

Bakke, H. \& B. Tveit: Serum levels of thyroid hormones in lines of pigs selected for rate of gain and thickness of backfat. Acta agric. scand. 1977, 27, 41-44.

Benjaminsen, E. \& K. Karlberg: Blodprøvetaking av gris. (Blood sampling in the pig.) Norsk Vet.-T. 1979, 91, 15-17.

Benjaminsen, E. \& K. Karlberg: Post weaning oestrus and luteal function in primiparous and pluriparous sows. Res. Vet. Sci. 1981, $30,318-322$.

Brenner, K. V., G. Pethes, H. Gürtler, S. Losonczy \& E. Grün: Thyroxinund Trijodthyroninkonzentration im Blutplasma von Schweinefeten und neugeborenen Ferkeln. (Thyroxine and triiodothyronine plasma concentrations in sows and newborn pigs.) Endokrinologie 1980, 75, 20-28.

Crooks, J., M. I. Tulloch, A. C. Turnbull \& G. Snædal: Comparative incidence of goitre in pregnancy in Iceland and Scotland. Lancet $1967,2,625-627$.

Cunha, T. J.: Mineral requirements of the pig. In Swine Feeding and Nutrition. Academic Press, New York 1977, pp. 33-73.

Gershengorn, M. G., D. Glinoer \& J. Robbins: Transport and metabolism of thyroid hormones. In The Thyroid Gland. Ed.: M. De Visscher. Raven Press, New York 1980, pp. 81-121.

Ingram, D. L. \& M. J. Dauncey: Effects of dietary composition on energy metabolism and rate of utilization of thyroxine. In Energy Metabolism. Ed.: L. E. Mount. Butterworths, London 1980, pp. $411-415$.

Isherwood, K. M. \& B. A. Cross: Effect of the suckling stimulus on secretion of prolactin and luteinizing hormone in conscious and anaesthetized rats. J. Endocr. 1980, 87, 437-444.

Kallfelz, F. A. \& R. P. Erali: Thyroid function tests in domesticated animals: Free Thyroxine Index. Amer. J. vet. Res. 1973, 34, 1449 -1451.

Kruse, V.: Production and evaluation of high-quality thyroxine antisera for use in radioimmunoassay. Scand. J. clin. Lab. Invest. 1976, 36, 95-101.

Larsen, P. R., J. Dockalova, D. Sipula \& F. M. Wu: Immunoassay of thyroxine in unextracted human serum. J. clin. Endocr. 1973, $37,177-182$.

Lennon, H. D. Jr. \& J. P. Mixner: Relationships between plasma protein-bound iodine and certain measures of reproductive and lactational performance in dairy cattle. J. Dairy Sci. 1959, 42, 327-332.

Mauget, R.: Seasonal reproductive activity of the European wild boar. Comparison with the domestic sow. In Environmental Endocrinology. Eds: I. Assenmacher \& D. S. Farner. Springer-Verlag, Berlin 1978, pp. 79-80. 
Miller, J. K., E. W. Swanson \& G. E. Spalding: Iodine absorption, excretion, recycling and tissue distribution in the dairy cow. J. Dairy Sci. 1975, 58, 1578-1593.

Mølmen, $K$. H.: Plasma protein bound iodine (PBI) in pigs from the 4th month of age, through the first oestrous cycles and during pregnancy. Zuchthygiene 1972, 7, 123-126.

Nachreiner, R. F. \& O. J. Ginther: Gestational and periparturient periods of sows: Serum chemical and hematologic changes during gestation. Amer. J. vet. Res. 1972a, 33, 2215-2219.

Nachreiner, R. F. \& O. J. Ginther: Gestational and periparturient periods of sows: Serum chemical, hematologic, and clinical changes during the periparturient period. Amer. J. vet. Res. 1972b, 33, 2233-2238.

Parvizi, N., F. Elsaesser, D. Smidt \& F. Ellendorff: Plasma luteinizing hormone and progesterone in the adult female pig during the oestrous cycle, late pregnancy and lactation, and after ovariectomy and pentobarbitone treatment. J. Endocr. 1976, 69, 193203.

Porter, J. C., D. D. Nansel, G. A. Gudelsky, M. M. Foreman, N. S. Pilotte, C. R. Parker Jr., G. H. Burrows, G. W. Bates \& J. D. Madden: Neuroendocrine control of gonadotropin secretion. Fed. Proc. 1980, 39, 2896-2901.

Potter, J. D.: Hypothyroidism and reproductive failure. Surg. Gynec. Obstet. 1980, 150, 251-255.

Robertson, H. A. \& G. J. King: Plasma concentrations of progesterone, oestrone, oestradiol-17 $\beta$ and of oestrone sulphate in the pig at implantation, during pregnancy and at parturition. J. Reprod. Fertil. 1974, 40, 133-141.

Scanlon, M. F., A. P. Weetman, M. Lewis, M. Pourmand, M. D. Rodriguez-Arnao, D. R. Weightman \& R. Hall: Dopaminergic modulation of circadian thyrotropin rhythms and thyroid hormone levels in euthyroid subjects. J. clin. Endocr. 1980, 51, 12511256.

Shoda, Y. \& T. Ishii: Effects of season, pregnancy and lactation on serum thyroxine level in dairy cattle. Jap. J. zootech. Sci. 1976, $47,659-664$.

Sutherland, R. L. \& C. H. G. Irvine: Total plasma thyroxine concentrations in horses, pigs, cattle and sheep: Anion exchange resin chromatography and ceric-arsenite colorimetry. Amer. J. vet. Res. 1973, 34, 1261-1265.

Thors $\varnothing e, H .:$ Inhibition of ovulation and changes in ovarian mucopolysaccharides induced by thyroidectomy in rabbits. Acta endocr. (Kbh.) 1962, 41, 441—447.

Visscher, M. De \& A. Burger: Evaluation of thyroid function; Diagnostic procedures in thyroid diseases. In The Thyroid Gland. Ed.: M. De Visscher. Raven Press, New York 1980, pp. 169-214.

Wilson, J. G.: Hypothyroidism in ruminants with special reference to foetal goiter. Vet. Rec. 1975, 97, 161-164. 


\section{SAMMENDRAG}

Plasma thyroxin hos purke under drektighet, laktasjon og under igangsettingen av ovarialfunksjonen etter avvenning.

Total thyroxin i plasma hos purke ble undersøkt under drektighet, laktasjon og $i$ perioden etter avvenning. Purkenes ovarialaktivitet ble unders $\varnothing \mathrm{kt}$ ved hjelp av progesteronmålinger, og eventuelle brunstsymptomer ble registrert. Hos de drektige purkene var det et tydelig fall $i$ thyroxinverdiene fra ca. en måned før partus, og konsentrasjonene nådde et minimum omtrent ved partus. Thyroxinverdiene var lave under laktasjonen, men fra avvenning og $i$ de f $\varnothing$ lgende to uker steg plasmakonsentrasjonene raskt. Det var ingen forskjell mellom thyroxinprofilen hos purker som gjenopptok syklisk ovarialfunksjon innen normal tid (10 dager) etter avvenning (72 purker) og thyroxinprofilen hos purker med forsinket igangsetting av syklisk ovarialfunksjon (19 purker). Purker med "stille brunst" hadde samme thyroxinm $\varnothing$ nster etter avvenning som purker med tydelige brunsttegn. Primipare og pluripare purker hadde heller ikke forskjell $i$ thyroxinverdiene etter avvenning. Purker som ble avvent $i$ tiden januar-juni hadde litt h $\varnothing$ yere thyroxinkonsentrasjoner etter avvenning enn purker avvent $i$ perioden juli-desember. Det var signifikant negativ korrelasjon mellom antall grisunger og thyroxinkonsentrasjonene f $\phi r$ avvenning. „Free thyroxine index“ ble beregnet $i$ et utvalg av prøver. Resultatet tyder på at de observerte forandringer $i$ totalthyroxin også indikerer forandringer $i$ konsentrasjonen av fritt thyroxin.

(Received March 27, 1981).

Reprints may be requested from: Edvard Benjaminsen, the Department of Reproductive Physiology and Pathology, Veterinary College of Norway, P.O. Box 8146, Dep., Oslo 1, Norway. 